\title{
Article
}

\section{Transforming Building Criteria to Evidence Index}

\author{
Géza Fischl *(D) and Peter Johansson (D) \\ Department of Construction Engineering and Lighting Science, School of Engineering, Jönköping University, \\ 55318 Jönköping, Sweden; peter.johansson@ju.se \\ * Correspondence: geza.fischl@ju.se
}

Citation: Fischl, G.; Johansson, P. Transforming Building Criteria to Evidence Index. Appl. Sci. 2021, 11, 5894. https://doi.org/10.3390/ app11135894

Academic Editor: Lavinia Chiara Tagliabue

Received: 16 May 2021

Accepted: 17 June 2021

Published: 24 June 2021

Publisher's Note: MDPI stays neutral with regard to jurisdictional claims in published maps and institutional affiliations.

Copyright: (c) 2021 by the authors. Licensee MDPI, Basel, Switzerland. This article is an open access article distributed under the terms and conditions of the Creative Commons Attribution (CC BY) license (https:// creativecommons.org/licenses/by/ $4.0 /)$.

\begin{abstract}
There is increasing pressure from developers toward architects and engineers to deliver scientifically sound proposals for often complex and cost-intensive construction products. An increase in digitalization within the construction industry and the availability of intelligently built assets and overall sustainability make it possible to customize a construction product. This servitization of construction products is assumed to perform much preferably in satisfying stakeholders' physical, psychological, and social needs. The degree to which these products are performing can be evaluated through an evidence index. This article aims to introduce a conceptual model of an evidence index and test it in the programming stage of a case study. The investigation follows the evidence-based design approach and renders evidence through key performance indicators in the programming stage of the building process. For testing the concept, a case study investigation was performed by simulating a novice research assistant, and the amount of evidence was collected and appraised for evidence index. The case study showed that key performance indicators of a servitized project could be evaluated on a four-point scale. The quality of the evidence index generation depended on the level of expertise the evaluator has in research and the skilful use of scientific databases.
\end{abstract}

Keywords: construction product; servitization; evidence-based design; level of evidence; cognitive buildings

\section{Introduction}

A typically assisted workflow by Building Information Modeling (BIM) process is the building performance evaluation [1], for instance, for energy consumption [2] and lighting [3], and air quality through simulations [4]. The optimal building performance can be achieved with technical considerations and a close fit between the building and its users' needs, providing comfort, health, and safety [5]. In terms of a computer-aided approach, development toward an easy-to-use data input is emerging for human behaviour regarding the programming and design phase. For improving design, a variety of quantitative approaches surfaced, like the probabilistic method [6], which reflects variation in the energy consumption models and the agent-based model (see, e.g., in $[2,7,8]$ ) that is investigating complex systems composed of interacting agents. In connection to building performance evaluation, a knowledge-oriented value generation process [1,7] in which stakeholders find satisfactory proofs, concerning key performance indicators (KPIs), treated like evidence for reasoning their needs and activities had surfaced. Key performance indicators are instrumental for optimizing the goals of the organization. The organizational goals are usually higher; meanwhile, the KPIs operationalise these goals and make them measurable, understandable, and actionable [8,9]. Therefore, KPIs in the programming and design phase of the building performance evaluation are often connected to the developer's detailed list of building criteria or physical attributes that are expected to be incorporated in the project. This detailed list of building criteria usually emerges through a long-term collaboration between the industry partners to ensure technical and functional service quality. One of this list is the Swedish Program for Technical Standard $[8,10]$, used in the case study below, a database for optimizing healthcare facilities' construction and design. The design criteria 
are set up with stakeholders, including the construction industry, to deliver a technical service solution to the users. This kind of servitization [11,12] is a key for delivering appropriate performance to stakeholders. In a traditional method, a building developer would provide a facility list that satisfies the needs in a technical/engineering approach, meanwhile, a servitized concept offers KPIs matching the stakeholders' personal needs. Today's technological possibilities allow building upon a new set of servitized construction products that are more efficient and less resource-intensive, connected through smart products and systems, and provide self-learning abilities that deliver an evidence-based optimization. For instance, lighting in an office is set to 200 lux as the general illuminance, but for well-being supportive lighting should include a glare-free setting that helps the individual. Furthermore, considering the daily intake of lighting energy for appropriate circadian rhythm functioning, the KPI should be supporting a human circadian rhythm. The critical issue here is how to assign the appropriate KPI for measuring the intended outcome. That is why researchers had turned their attention to evidence-based design (EBD) as a design method from the field of evidence-based medicine [13]. EBD for the built environment can be defined as the process of design decisions on credible research and lessons learned from previous design experiences as evidence to achieve the best possible outcomes [14,15]. EBD is the antecedent of the building performance evaluation $[16,17]$ and recent research has shown how EBD can be connected to digital tools, like lighting simulations [18]. This research has identified the importance of selecting KPIs (or metrics) for identifying evidence [19] during the evidence-based optimization (EBO). EBO and the current development of cognitive abilities of the building system could lead to better servitization of construction products (Figure 1).

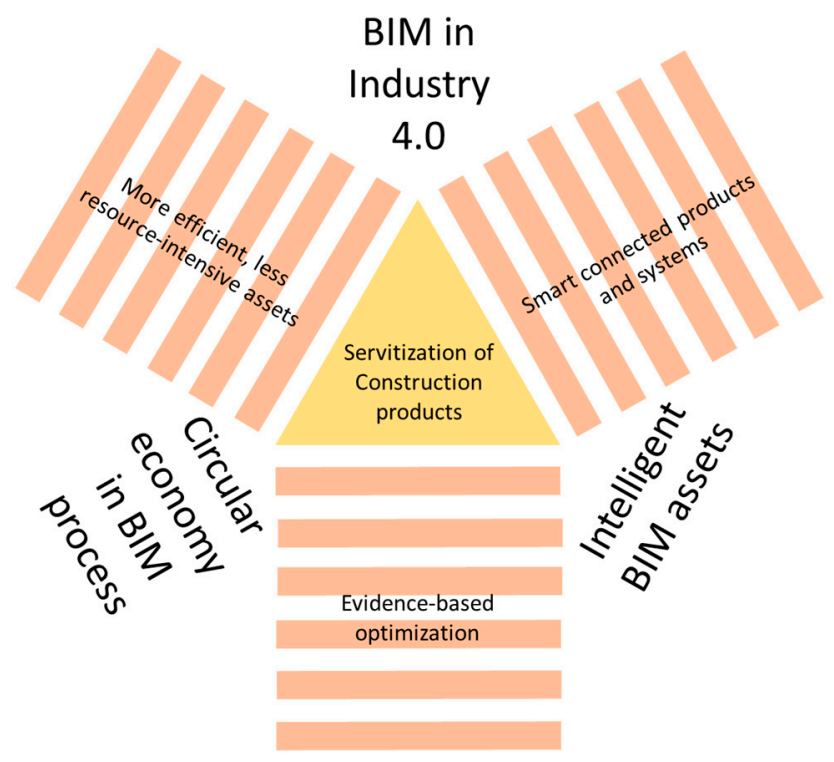

Figure 1. Servitisation of construction product in the context of BIM in Industry 4.0, Circular economy, and Intelligent Building Information Modeling (BIM) assets (Adapted from CPA, [20]; p 17).

Promoters of EBO may be representatives of developers, architecture designers, clients, users, researchers, and facility managers for improving an individual's physical, psychological, and social qualities together with environmental sustainability. From this perspective, the attainment of stakeholders' values would ensure the successful implementation of resources to the predefined goal. A possible measure of reaching the predefined goal is to assess an evidence index for all physical attributes or components listed in the building criteria; henceforth, early in the programming stage, the expected evidence index can indicate how well the predefined goals in the building criteria are in line with a scientific level of evidence. 
Consequently, this article aims to introduce and, through a case study, test an evidence index capable of describing the level of evidence at the programming stage of a building process. It is assumed that a novice investigator can generate an evidence index, but the results need to be further scrutinized.

\section{Methodology}

In this section, the first conceptual method of an evidence index is described, and an enhancement of the EBD process with a cognitive building concept is suggested. Consequently, a case study focusing on an administrative office is tested with the suggested evidence index framework.

\subsection{Establishing Evidence Index}

The concept of an evidence index (EI) in a room or a building is complementing a post-occupancy evaluation method (POE) (see, e.g., in [21]). POEs have been around for several decades [16], and the depth of investigations is generally made on three distinct levels [22] (indicative, investigative, and diagnostic). A post-occupancy evaluation system arose for feedbacking stakeholders in building projects regarding how well the building performs after its inauguration in terms of user's satisfaction, energy performance, indoor environmental quality, and sustainability. An EI's conceptual development is originated in the EBD process [23]. The intention with a single value on a room/building project is to inform the stakeholders about the verified level of evidence that the building criteria is setting. As building criteria may arise from a previous POE and most likely a new project organization would introduce these additional values for the programming stage, this act of organizational learning [24] was the forerunner of a cognitive building. Cognition in terms of information processing requires working memory (POE) and long-term memory (building criteria, KPIs) in order to appraise information (evidence) for appropriate response selection [25] (project outcome). Consequently, the state-of-the-art understanding of the cognitive building solution is a sustainable building system that automatically integrates, analyses, and learns from the IoT-generated data [26]. The EI would be benefitting the cognitive building concept through the interconnectedness of scientific databases and machine learning of evidences in scientific publications to find and appraise a project-specific evidence index. For this to become a reality, more knowledge about EBD and EI is needed, and the work described here is a contribution to that.

\subsubsection{Evidence-Based Design Process for Cognitive Buildings}

POE is an integral part of the EBD process [3,18], which distinguishes between eight phases that refer to a continuous workflow stepwise progression. The modified EBD process fitted to a servitized construction product for cognitive building solution may include the following:

1. Defining the key goals and objectives: A vision is developed for the intentions, directions, and goals for the project. The multidisciplinary project team and a cognitive building solution articulate the goals and objectives to be reached. This process includes similar project-specific digitalized POE results and KPIs that proved to be appropriate and accurate for the type of the planned project.

2. Finding of sources for relevant evidence: A relevant evidence is obtained mainly from various digitalized scientific and expert testimonial databases to identify research results that may serve as evidence. This process requires robust digitalization and machine learning to locate evidence.

3. Critical interpretation of relevant evidence: The validity and reliability of the evidence need to be established by review. The automatized process of finding and evaluating the level of evidence in every project related sources is due to the fine-tuned algorithms capable of understanding and interpreting scientific results and closing the gap between evaluators. Informing the design phase and creating hypotheses for value generation also starts here. 
4. Creation and innovation of evidence-based design concepts: The relevant evidence is translated into design guidelines and statements. Designers use guidelines for aesthetic, functional, or compositional decisions and incorporate digital tools to visualize the project. The cognitive building concept helps to prioritize among the possible design solutions due to its iterative design capabilities. The possible alternatives are tested in a parametric environment.

5. Development of hypotheses: Design hypotheses are generated and tested by various means. The parametrized design solutions are being evaluated mathematically and/or visually in order to set the subjective and objective method for hypothesis testing.

6. Collection of baseline performance measures: The building criteria with the embedded level of evidence are identified and assessed. The project values and requirements are translated into parametric design criteria expressed in terms of performance metrics and simulation results.

7. Monitoring of implementation of design and construction: With the help of cognitive building solution, the construction is monitored, and the project team makes sure that the design strategies are executed and delivered. In terms of deviation from the planned action, the cognitive building solution is waiting for human approval of the deviations. At the end of construction, the project team and the cognitive building solution verifies that the project is ready for post-occupancy research.

8. Measurement of post-occupancy performance measure: The project-specific KPIs are being analysed in situ or virtually. The necessary adjustments are made in the physical environment to match the stakeholders' expectations.

The above-suggested EBD process for cognitive building solution is still ahead of the present reality. However, for the realization of the EI in a non-cognitive building solution, the first three stages of the original EBD process are considered in this article. Starting with the definition of goals and objectives that describes the planned building project's intentions and direction. A team of decision-makers articulate project goals in terms of their desired outcomes. In the case of a well-known building typology to be delivered, the project goals and objectives are revisited from previous successful projects using POE. These building criteria may be industry standards and recommendations. In case of an innovative solution, building criteria are being set intuitively according to the team's experience. When this preliminary programming of domain-specific values is set, the next stage is finding sources for relevant evidence.

\subsubsection{Finding Evidence}

Relevant evidence is gathered mainly from scientific literature to identify gaps in knowledge and determine what relevant research has already been performed and which needs to be researched. Peavey and Vander Wyst [27] differentiate between evidence that incorrectly refers to a proof of a design decision. This misconception is caused by the difference between the commonly used definition of evidence as proof and the scientific interpretation of evidence. The latter divide evidence into several levels. Another shortcoming of using evidence as a proof is reported by Cama [28] when the practitioner indistictively using the evidence for any kind of built environment. To overcome such a misinterpretation of evidence, a critical interpretation is needed.

The methodological framework for ranking evidence is combined from a series of research design methods that gradually decrease the need for scientific rigour, validity, and reliability. Therefore, the evaluation of the level of evidence prerequisites a qualified person to interpret the specific evidence in accordance with an EBD guideline. This guideline was moulded from Pati [29], Stetler [30], and Stichler [31] recommendations for healthcare design settings (Table 1 ). 
Table 1. Levels of evidence as it is originated from healthcare design.

\begin{tabular}{|c|c|}
\hline Ranking & Evidence-Based Design \\
\hline 1 & $\begin{array}{l}\text { Meta-analysis and systematic reviews of randomized controlled trials or } \\
\text { experimental studies }\end{array}$ \\
\hline 2 & Single experimental study (randomized, controlled) \\
\hline 3 & Single quasi-experimental study (randomized, concurrent, or historical controls) \\
\hline 4 & $\begin{array}{l}\text { Systematic, interpretive, or integrative review of multiple studies of observational or } \\
\text { qualitative research }\end{array}$ \\
\hline 5 & $\begin{array}{l}\text { Single non-experimental study, correlational, descriptive, mixed methods, and } \\
\text { qualitative research }\end{array}$ \\
\hline 6 & $\begin{array}{l}\text { Published evaluation data (e.g., facility evaluations, mock-ups) that were } \\
\text { systematically collected and were verifiable }\end{array}$ \\
\hline 7 & $\begin{array}{l}\text { Consensus opinion of authorities (e.g., a nationally known guideline group with } \\
\text { strong peer review) }\end{array}$ \\
\hline 8 & Opinions of recognized experts, case studies \\
\hline
\end{tabular}

Note. Adapted from Pati [29], Stetler [30], and Stichler [32]. These levels should be used in conjunction with a critical appraisal of quality at each level.

In a building project, ranking of evidence in the early project phase is imperative because it has a significant outcome for the programming stage that will impact the stakeholders' physical, and psychological and social wellbeing. At the critical interpretation of relevant evidence, awareness about potentially misinterpreted evidence can still be resolved in time before the project is suffering from serious financial expenses. However, the level of evidence may require qualified personnel in research methodology who can rank the scientific evidence and still give credits for opinions and individual observations. A categorization of such a comprehensive source of information should be guided by a value-generation process that gives meaning to complicated interpretations of the scientifically produced evidence. Marquardt and Motzek [33] suggested a helpful algorithm for architects and designers to critically appraise the quality of evidence in EBD. By adopting a four-level scale instead of a six-level, as Marquardt and Motzek [34] suggested, the investigation of the quality of evidence may take less time to perform with less trained personnel. To appraise the level of evidence into a four-point scale, Evans (2003, p. 82) published a hierarchy to an indication of the validity and trustworthiness of different types of research. This process assists in the selection of the evidence to guide evidence-based clinical practice. However, a building delivery process is not seen directly as a comparable field of study to clinical practice, yet its systematic research-based approach to identification of evidence makes it possible to apply the principles of research to designers and engineering practitioners. Henceforth, the proposed four-point rating scale is the first attempt to measure the level of evidence in servitized construction delivery using EBD. The highest rating is excellent, when the evidence provides the strongest scientific base for the practice. This evidence level is at the least risk of error, therefore it is optimal for the development of practical design guidelines and recommendations. The next highest level is good. This rating provides a sound basis for practical cases and is at low risk of error. However, as it may have been generated by single studies, it also highlights areas where replication of research is needed. A less prefered rating is fair, which includes varying degrees of risk for error, and it does not provide a strong evidence for the practice. These studies usually represent exploration of interventions. The rationale behind this level is to accept a greater risk of error in the evidence, yet allow further identification of potentially beneficial KPIs that require additional investigation and evaluation. The least preferred and most common level of evidence can be ranked as poor, when there is a weak basis for practical use and is at serious risk of error or bias. The four-point scale rating has an advantage on the usability side as an evaluator is forced to avoid central tendencies and needs to be making a decision based on the criteria at hand [35]. The drawback of this four-point scale is tangible when the accuracy of the level of evidence is in question. In the EBD process, the scientific evaluations should be synchronized to laypersons or design 
experts too. A four-point category suggested on quality of evidence is summarized and retains the major scientific category differences and the contents (Table 2).

Table 2. Modified levels of evidence for quantitative research and EBD project.

\begin{tabular}{cl}
\hline Level & \multicolumn{1}{c}{ Determining the Level of Evidence } \\
\hline Excellent & $\begin{array}{l}\text { Meta-analysis and systematic reviews of randomized controlled trials or } \\
\text { experimental studies; Single experimental study (randomized, controlled) }\end{array}$ \\
\hline Good & $\begin{array}{l}\text { Single quasi-experimental study (randomized, concurrent, or historical controls); } \\
\text { Systematic, interpretive, or integrative review of multiple studies of observational or } \\
\text { qualitative research }\end{array}$ \\
\hline Fair & $\begin{array}{l}\text { Single non-experimental study, correlational, descriptive, mixed methods, and } \\
\text { qualitative research; Published evaluation data (e.g., facility evaluations, mock-ups) } \\
\text { that were systematically collected and were verifiable }\end{array}$ \\
\hline Poor & $\begin{array}{l}\text { Consensus opinion of authorities (e.g., a nationally known guideline group with } \\
\text { strong peer review); Opinions of recognized experts, case studies }\end{array}$
\end{tabular}

Note: Adapted from Pati [29], Stetler [30], and Stichler [32]. These levels should be used in conjunction with critical appraisal of quality at each level.

\subsubsection{Critical Review of LOE}

Two flow chart diagrams visualize the decision-making procedure evaluating the level of evidence (LOE) with a quantitative or qualitative study by Marquardt and Motzek [33]. These algorithms for rating the evidence distinguishes among six-levels LOE according to Stichler [32]. The step-by-step procedure follows "yes" and "no" options for the main methodological junctions. The answers on these methodological alternatives will eventually lead the rater to various level of evidence. A four-level LOE category is presented in relation to the major study types in Figure 2. When a qualitative or case study is investigated in an interpretative way, the rater evaluates if the study has a literature review, a framework, a clear method reported, and the diversity of views are represented, then the LOE might be reaching a fair rating. When these aspects are not addressed in the study, it is assigned as poor. For instance, a case study describing the renovation of a building is classified as poor, but if the study features several buildings with the same typology, including stakeholder interviews, and has a matching methodology, it is assigned to fair. The quantitative study employs statistical analyses and measures outcomes, therefore they belong to the observational study category. These can be a panel, cohort, case-control, and cross-sectional studies. A sample is followed over a period in a panel study, and the effects of exposures are examined. All observational studies are assigned to fair, considering a set of samples compared to each other in a methodologically appropriate way. In an experimental study, when the participants are randomly allocated to at least two randomized selected groups and compared under two or more conditions, the study can be called a randomized controlled trial (RCT). In this type of study, one group receives treatment, while the other group does not. The measurements taken in both cases are before and after the treatment.

When the groups are not randomized but grouped due to specific characteristics, the study is considered as quasi-experimental. In some quasi-experimental studies using within-subject tests, the measurements are taken before and after the intervention. If an experimental or quasi-experimental study is well-conducted, it is classified as good, otherwise as fair. These types of studies are well-conducted if (1) there are two separate groups of participants; (2) there is a low gradual reduction rate, under $20 \%$; (3) the outcomes are analyzed according to initial treatment assignment; and (4) there are reliable outcomes with low dispersion. Additionally, an experimental RCT study is well conducted and can be assigned as good if there is a low ascertainment bias at sampling and the study maintain a high quality of blinding of participants and the researcher. 

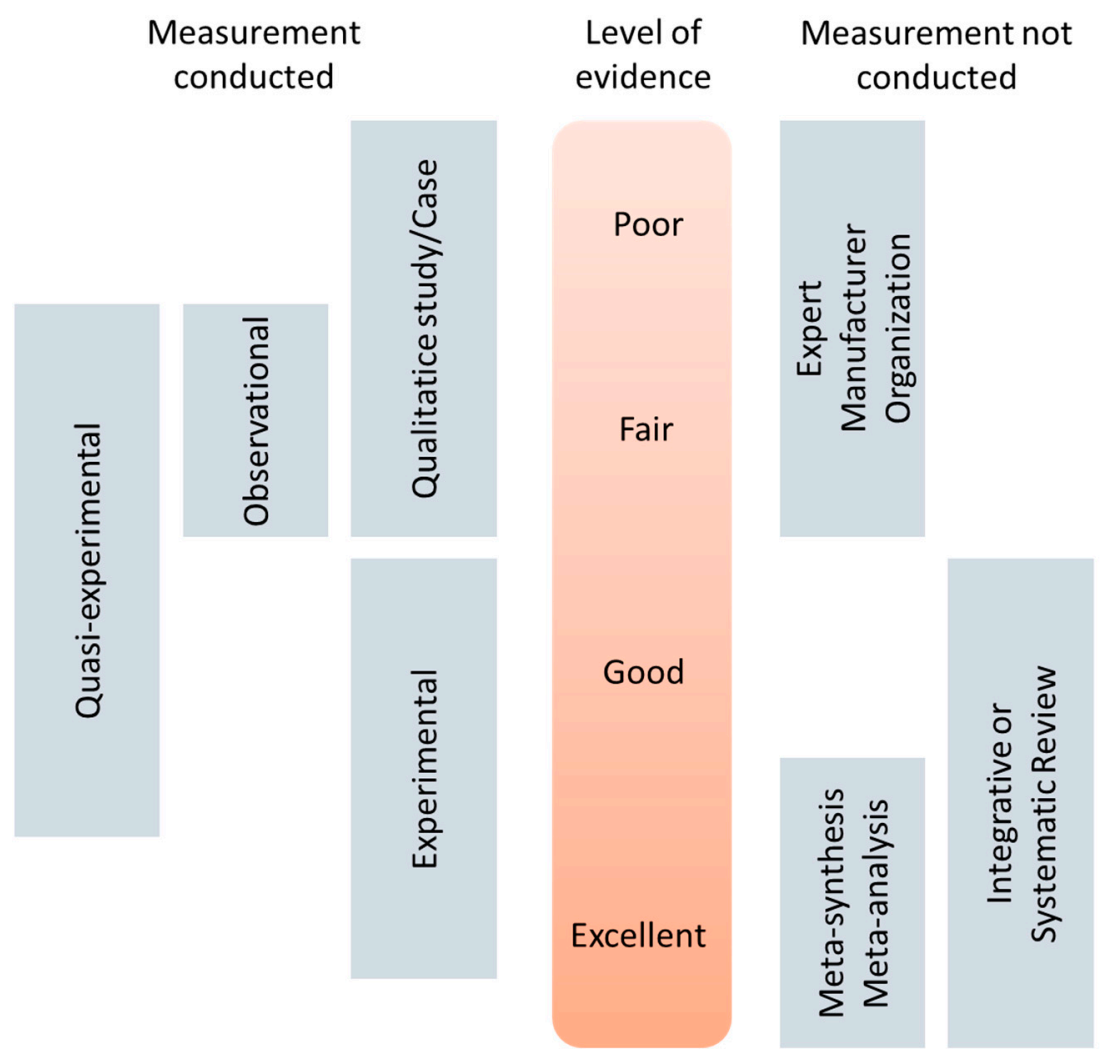

Figure 2. Study types in relation to the four-point scale of the level of evidence (LOE). Modified after Marquardt and Motzek [33].

The right side of the diagram (Figure 2), deals with nonsystematic, systematic, and mixed methodology papers. The nonsystematic refers to studies from manufacturers or consultants, including experts' opinions and guidelines of professional organizations and standards. The scientific robustness of the papers is lacking and the critical approach to the investigations is missing. Furthermore, these studies might have financial interest bias. These nonsystematic papers are all rated as poor. In contrast to this, the systematic reviews and meta-analyses identify, evaluate, and summarize objective and accurate approaches rated as excellent evidence. Meanwhile, in the systematic review and the integrative review with lower quality of study design, the studies summarize merely empirical or theoretical views, therefore they reach a fair level.

\section{Case Study Application}

The Real Estate (Regionfastigheter) organisation of Jönköping's County Council in Sweden has developed an IT-based management system for controlling and supporting its building process, called Program of Technical Standard (PTS). PTS is a knowledge database containing best practice and specific knowledge about how the building of premises for healthcare should be carried out. PTS is a widely accepted building criteria recommendation in 20 of the 21 County Councils in Sweden [36]. Among other things, PTS contains standard room requirements for various interior amenities and functions.

The case study involved an administrative office (approximately $10 \mathrm{~m}^{2}$; but at least $4.2 \mathrm{~m} \times 2.1 \mathrm{~m}$, Figure 3) from PTS. The detailed list of building criteria for the single person occupancy administrative office was obtained through Regionfastigheter Jönköping, Sweden. The building criteria in the PTS are not explained or categorized in any specific way, making it rather difficult for formulating a prioritization about it. Therefore, the investigation of the list of building criteria was first categorized and later searched to find the value and possible evidence related to the particular criteria. 


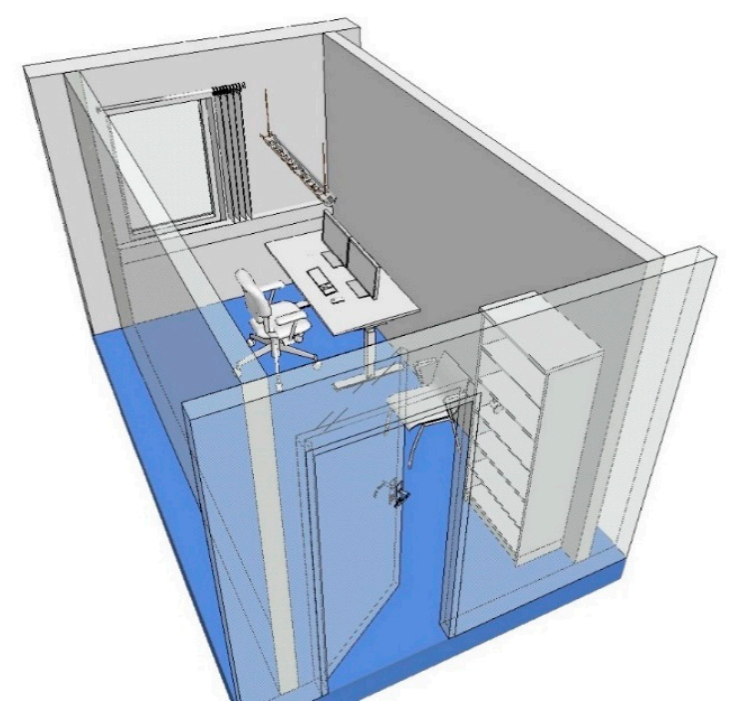

Figure 3. BIM model of administrative office typology visualized after the (After Program of Technical Standard) PTS building criteria. This visualization is done by ArchiCAD 22 Educational edition, Jönköping university.

The case study aimed to investigate the evidence index for this single office occupancy in the programming phase of the design process.

\subsection{Procedure and Analysis}

The case study procedure followed Table 3 steps to generate the EI. The manual steps are summarized which are set to make an EI for a servitized construction product. After identifying stakeholder as administrative personnel, the EBD process started. The building typology was set for a healthcare facility, and the building criteria were extracted from the PTS. The evidence and the domain of the evidence were described in each finding. The project relevance was chosen to be on a four-point scale: poor (1), fair (2), good (3), and excellent (4). The applicability of this four-point scale was earlier described. The priority of evidence to be used in the EI calculation was set between low (1), medium (2), or high (3). The assessment process did not aim to collect as many evidence as possible within one building criterion, instead as a general approach it aimed to provide at least one evidence for each criterion. The decision behind this category scale is the ease of use for the rater to set up a quick cognitive process. The LOE was appraised using the diagram of Figure 2 and the reference for the related evidence was indicated. The LOE was set between poor (1), fair (2), good (3), and excellent (4) depending on the scientific approach.

Table 3. Procedure to generate the Evidence index for a servitized construction product.

\begin{tabular}{lll}
\hline \multicolumn{2}{c}{ Procedure to Generate the Evidence Index } \\
\hline $1 . \quad$ Identifying Stakeholder & To whom? \\
$2 . \quad$ EBD process & $1-8$ stages \\
2.1 Category & Building typology \\
2.2 Building criteria (KPI) & Physical attributes \\
2.3 Values & What domain? \\
2.4 Evidence & What exactly \\
2.5 Relevance & $1,2,3,4$ (Poor, Fair, Good, Excellent) \\
2.6 Priority & $1,2,3$ (Low, Medium, High) \\
3. Level of evidence (LOE) $\quad$ EI & $1,2,3,4$ (Poor, Fair, Good, Excellent) \\
4. $\quad$ Reference & (Relevance $\times$ Priority $\times$ LOE) $/ 2$ \\
$5 . \quad \quad$ Indicative \\
\hline
\end{tabular}


The appraisal of the EI resembled a novice research assistant searching strategy, implying that the person first uses Google or Google scholar engine and, if it is not successful, then uses a university library access for scientific literature.

\subsection{Results and Discussion}

The results are presented in Table 4 . Altogether, 42 building criteria were taken into consideration when identifying 30 evidence. Among the evidence, best practice indicated a not identified evidence, therefore it was assumed that the building criteria is based on a practical need existing in the construction and use phases. The values for these items were not calculated and counted into the EI. Consequently, the final value on EI was 1.49, which is slightly better than a poor level but not reaching fair. Due to the high number of best practice designations, the novice research assistant had difficulties identifying the scientific evidence describing why specific building criteria exist. As a consequence of this finding, the level of expertise in evaluating healthcare buildings needs to be higher. Regarding the usability of the four-point scale LOE appraisal, it put a high demand on the evaluator to clearly identify the strength of evidence. However, when using internet forums or opinions for the search, the diagram could not be considered for appraising the evidence level. These building criteria were treated as best practices.

Table 4. Transformation of building criteria into evidence index.

\begin{tabular}{|c|c|c|c|c|c|c|c|c|c|}
\hline 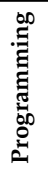 & 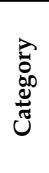 & Building Criteria & Values & Evidence & Reference & 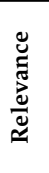 & 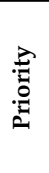 & อొ & 可 \\
\hline \multirow{15}{*}{ 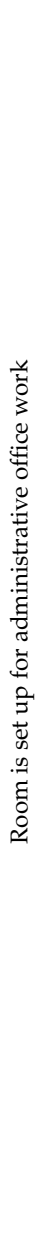 } & \multirow{9}{*}{ 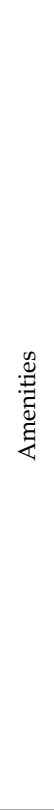 } & Cloth hangers & comfort & Best practice & & & & & \\
\hline & & \multirow[b]{3}{*}{ 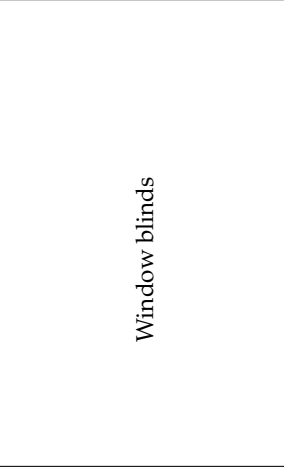 } & electricity saving & $\begin{array}{l}\text { 1. obtained electricity savings for lights (with the window system } \\
\text { and controllable highly reflective venetian blinds plus light } \\
\text { dimming) reaching } 76 \% \text { on overcast days and } 92 \% \text { on clear days }\end{array}$ & [37] & 1 & 2 & 2 & 0.33 \\
\hline & & & $\begin{array}{l}\text { best utilization of } \\
\text { blinds }\end{array}$ & $\begin{array}{l}\text { 2. of daylight is achieved with horizontal slats, because this evens } \\
\text { out the big differences in luminances between the window zone } \\
\text { and the rear wall zone }\end{array}$ & [38] & 4 & 3 & 3 & 3.00 \\
\hline & & & $\begin{array}{l}\text { threshold value } \\
\text { for action }\end{array}$ & $\begin{array}{l}\text { 3. a threshold value of } 2000 \mathrm{~cd} / \mathrm{m}^{2} \text { was used, based on the } \\
\text { assumptions that the primary task involved a LCD computer } \\
\text { monitor with an average luminance of } 200 \mathrm{~cd} / \mathrm{m}^{2} \text {. The window } \\
\text { was within the occupant's peripheral field of view so that a } \\
\text { maximum luminance ratio of } 10: 1 \text { between window and task was } \\
\text { just acceptable, and that the average background luminance was } \\
50-100 \mathrm{~cd} / \mathrm{m}^{2} \text {. It was also based on subjective survey results that } \\
\text { found that there was a } 50 \% \text { probability that blinds would be } \\
\text { lowered when the average window luminance was } 2100 \mathrm{~cd} / \mathrm{m}^{2}\end{array}$ & [39] & 3 & 3 & 2 & 1.50 \\
\hline & & $\begin{array}{l}\text { Electrical wiring in } \\
\text { walls, beside the door }\end{array}$ & & Best practice & & & & & \\
\hline & & Electrical outlet & & Best practice & & & & & \\
\hline & & \multirow{2}{*}{$\begin{array}{l}\text { General lighting: up and } \\
\text { down }\end{array}$} & well-being & 1. General lighting for writing task: Em = 500 lx; & [40] & 4 & 3 & 1 & 1.00 \\
\hline & & & efficiency & $\begin{array}{l}\text { 2. Indirect light is more expensive to install, but } 20 \% \text { more energy } \\
\text { efficient as indirect alone, light wall and ceiling color is needed }\end{array}$ & [41] & 3 & 3 & 2 & 1.50 \\
\hline & & $\begin{array}{l}\text { Combined outlets } \\
\text { (telephone, data) }\end{array}$ & comfort & Best practice & & & & & \\
\hline & \multirow{6}{*}{ 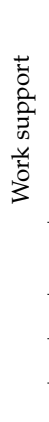 } & \multirow{2}{*}{$\begin{array}{l}\text { Vertically adjustable } \\
\text { desk }\end{array}$} & awareness & $\begin{array}{l}\text { 1. Desks may be an important remedy in this endeavor, } \\
\text { particularly in office settings, while ergonomics awareness may be } \\
\text { able to contribute to further changes in sedentary behavior if } \\
\text { enhanced and if supported by the work organization. }\end{array}$ & [42] & 4 & 3 & 3 & 3.00 \\
\hline & & & well-being & $\begin{array}{l}\text { 2. The ability to alter one's position by sitting, standing, and } \\
\text { walking is healthier than sitting continuously with } 90 \text { degree } \\
\text { angles in knees and hips }\end{array}$ & [43] & 4 & 3 & 1 & 1.00 \\
\hline & & $\begin{array}{l}\text { Bookshelf }(\mathrm{L}=800 \mathrm{~B}= \\
\quad 420 \mathrm{H}=1700)\end{array}$ & comfort & Best practice & & & & & \\
\hline & & Visitor's chair & comfort & Best practice & & & & & \\
\hline & & Curtain rod & control & Best practice & & & & & \\
\hline & & Curtain hanger & control & Best practice & & & & & \\
\hline
\end{tabular}


Table 4. Cont.

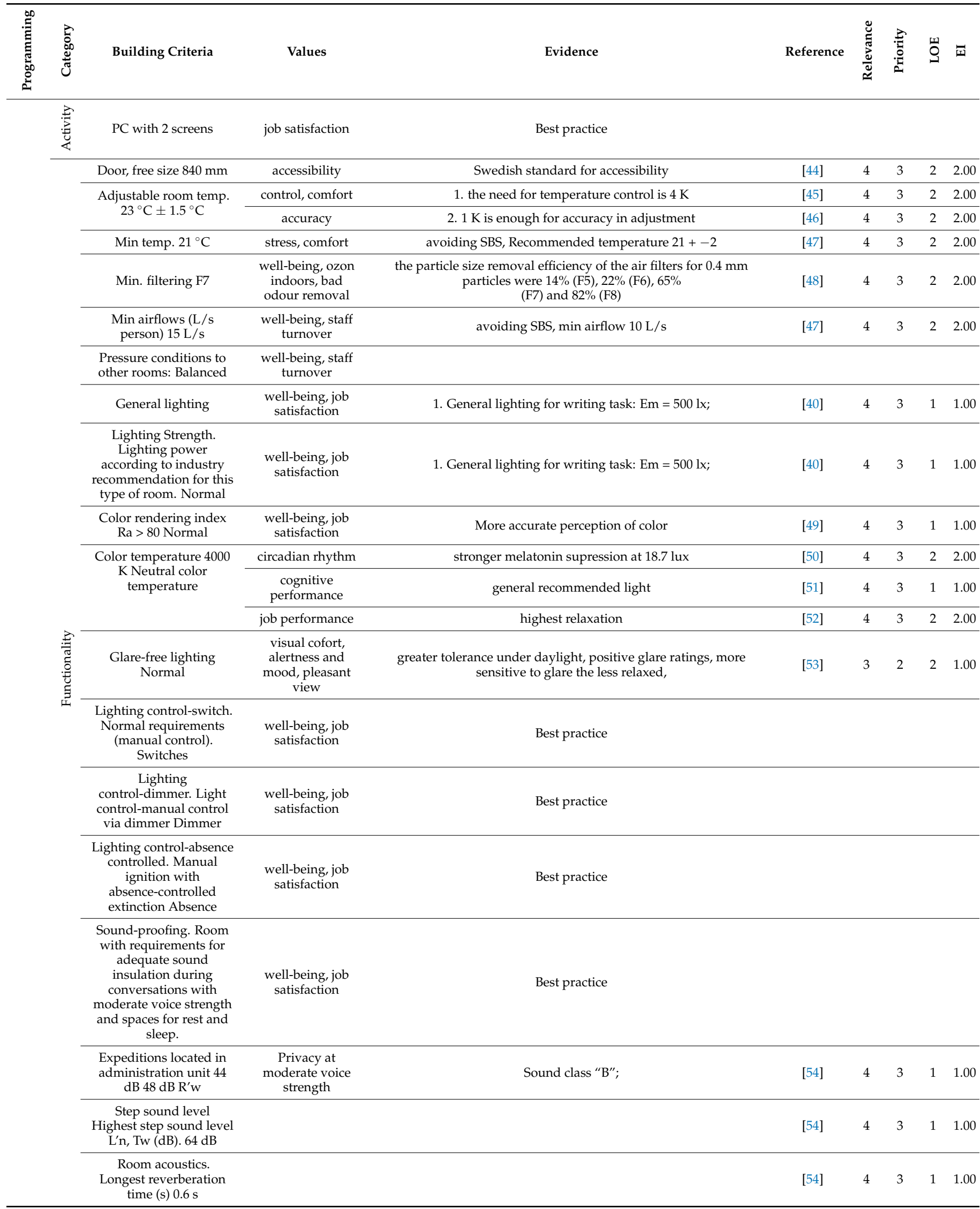


Table 4. Cont

\begin{tabular}{|c|c|c|c|c|c|c|c|c|c|}
\hline 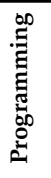 & 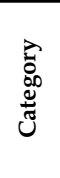 & Building Criteria & Values & Evidence & Reference & 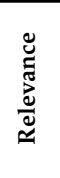 & 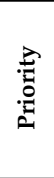 & 임 & 可 \\
\hline & & $\begin{array}{l}\text { Noise from installations. } \\
\text { Rooms with moderate } \\
\text { requirements for sound } \\
\text { levels. } 35 \mathrm{~dB}(\mathrm{~A})\end{array}$ & & & [54] & 4 & 3 & 1 & 1.00 \\
\hline & & $\begin{array}{l}\text { Daylight Requirements } \\
\text { are required }\end{array}$ & $\begin{array}{l}\text { visual cofort, } \\
\text { alertness and } \\
\text { mood }\end{array}$ & $\begin{array}{l}\text { 1. Reduced discomfort; } 2 \text {. Improves circadian rhythm, 3. Max. } \\
\text { visual performance, } 4 \text {. Mood changes }\end{array}$ & {$[55,56]$} & 4 & 3 & 2 & 2.00 \\
\hline & & $\begin{array}{l}\text { Power lighting. In\% } \\
\text { connected lighting ÖL } \\
50 \% \text { VL 50\% }\end{array}$ & $\begin{array}{l}\text { well-being, job } \\
\text { satisfaction }\end{array}$ & Best practice & & & & & \\
\hline & & $\begin{array}{l}\text { Power take-off } 230 \mathrm{~V} \text {. } \\
\text { In } \% \text { connected outlets or } \\
\text { loads ÖL } 50 \% \text { VL } 50 \%\end{array}$ & $\begin{array}{l}\text { well-being, job } \\
\text { satisfaction }\end{array}$ & Best practice & & & & & \\
\hline & & $\begin{array}{l}\text { Power take-off } 230 \mathrm{~V} \\
\text { data. Very Important } \\
\text { Last MVL 100\% }\end{array}$ & $\begin{array}{l}\text { well-being, job } \\
\text { satisfaction }\end{array}$ & Best practice & & & & & \\
\hline & & $\begin{array}{c}\text { Medical spaces. } \\
\text { According to SS } 43640 \\
00 \text { ch. } 710 \text { Group } 0\end{array}$ & $\begin{array}{l}\text { well-being, job } \\
\text { satisfaction }\end{array}$ & Electrical installation rules & $\begin{array}{l}\text { [57] ch. } \\
710 \\
\text { Group } 0\end{array}$ & 4 & 3 & 1 & 1 \\
\hline & & $\begin{array}{l}\text { Shooting signal. } \\
\text { Indicator tab for busy } \\
\text { marking. Switching on } \\
\text { and off at the door }\end{array}$ & $\begin{array}{l}\text { well-being, job } \\
\text { satisfaction }\end{array}$ & Best practice & & & & & \\
\hline & & View towards greenery & Stress reduction & $\begin{array}{l}\text { Short-term visits to urban nature areas have positive effects on } \\
\text { stress relief. }\end{array}$ & {$[58,59]$} & 4 & 3 & 2 & 2.00 \\
\hline & & & $\begin{array}{l}\text { Cortisol } \\
\text { reduction }\end{array}$ & $\begin{array}{c}\text { The salivary cortisol concentration decreases in all urban } \\
\text { environments. }\end{array}$ & [58] & 4 & 3 & 2 & 2.00 \\
\hline & & & Noise reducer & Accessibility may not reduce noise annoyance & [60] & 2 & 1 & 2 & 0.33 \\
\hline & & Hygiene class 2 & Hygiene & $\begin{array}{l}\text { Surface layers on walls must withstand cleaning agents and point } \\
\text { disinfection }\end{array}$ & [61] & 4 & 3 & 1 & 1.00 \\
\hline & & Locking Mechanical lock & $\begin{array}{l}\text { well-being, job } \\
\text { satisfaction }\end{array}$ & Best practice & & & & & \\
\hline & 造 & $\begin{array}{l}\text { Flooring Carpet } \\
\text { upholstered against the } \\
\text { wall }\end{array}$ & safety & Best practice & & & & & \\
\hline & 星 & $\begin{array}{l}\text { Wall. Painted, gloss } \\
\text { value } 20\end{array}$ & $\begin{array}{l}\text { well-being, job } \\
\text { satisfaction }\end{array}$ & Best practice & & & & & \\
\hline
\end{tabular}

\section{Discussion}

Gedda [62] published an inspirational article on evidence index that is related to evidence-based medicine, in which the author refers to the evidence index as the "factual components on which the main decision-making is based" (p. 1) during a treatment. As evidence-based medicine gave rise to evidence-based design, the promoters of EBD rely on objective scientific data combined with stakeholders' perspective and expertise in the building project. Considering a complex construction project where building criteria are detailed and consensus-based among the partners, an evidence index could be validating the objectivity of the criteria set to fulfil the stakeholders' needs. However, the often servitized and multifaceted criteria in the era of digitalization can be the source of confusion with regards to prioritization between the building criteria to fulfil the project goals. Therefore, this study aimed to test an evidence index during the programming stage of a building process in order to understand the level of objective scientific data involved in the decision making. The study assumed that even a novice investigator could generate an evidence index.

The methodological development for the EI is fundamentally striving for a quantifiable measurement for the stakeholders' interests. The building performance evaluation (BPE) 
had always been a building process-oriented approach, and on a larger scale, it incorporates the quantitative research characteristics and the EBD process model. The EBD process model is a combination of quantitative research and a building project process model. Therefore, the use of EBD as the primary process model for EI generation seemed viable (Table 5).

Table 5. The main steps for quantitative research (after Polit and Beck [63] and Stichler [31]), evidencebased design (EBD) [23], and building performance evaluation (BPE) [17] are shown.

\begin{tabular}{|c|c|c|c|}
\hline Steps & Quantitative Research & BPE & EBD \\
\hline 1 & $\begin{array}{l}\text { Identify problem, research } \\
\text { question, or hypothesis (es) }\end{array}$ & Market/Needs analysis & $\begin{array}{l}\text { Define evidence-based goals and } \\
\text { objectives (with client and } \\
\text { interdisciplinary team }\end{array}$ \\
\hline 2 & Perform literature review & \multirow[b]{2}{*}{ Program review } & Find sources for relevant evidence \\
\hline 3 & $\begin{array}{l}\text { Use of a theoretical framework } \\
\text { to explain the relationships } \\
\text { among variables }\end{array}$ & & $\begin{array}{l}\text { Critically interpret relevant } \\
\text { evidence, assess evidence } \\
\text { applicability, quality and strength }\end{array}$ \\
\hline 4 & $\begin{array}{l}\text { Select an appropriate research } \\
\text { design to test the hypothesis }\end{array}$ & Design review & Create and innovate EBD concepts \\
\hline 5 & $\begin{array}{l}\text { Identify measurements to } \\
\text { quantify variables }\end{array}$ & \multirow{2}{*}{ Effectiveness review } & Develop a hypothesis \\
\hline 6 & Select the sample & & $\begin{array}{l}\text { Collect baseline performance } \\
\text { measures }\end{array}$ \\
\hline 7 & Data collection and analysis & Commissioning & $\begin{array}{l}\text { Monitor implementation of design } \\
\text { and construction }\end{array}$ \\
\hline 8 & Statistical data analysis & \multirow[b]{2}{*}{ POE } & \multirow[b]{2}{*}{ POE } \\
\hline 9 & $\begin{array}{l}\text { Disseminate results in } \\
\text { publications and presentations }\end{array}$ & & \\
\hline
\end{tabular}

The development of EI in this paper mainly focuses on the programming stage, which is an early stage of the building process, but this is the strategically important stage, where servitized construction products review scientific evidence on how well they can support the predefined goals. Theoretically, the EI could be extended throughout the entire EBD or $\mathrm{BPE}$ process and inform the stakeholders about the whole building process. The cognitive building solution for delivering EI for a building project is a challenging task. Today, the initial stages within the EBD process had been made by manual effort and resulted in a case study quality. However, the results showed that it was possible to generate an EI value between 1 and 4 on the rating scale and indicate the room EI, the process was time-consuming and often assigning best practice for reasoning for the building criteria. The frequent occurrence of best practices indicates that the level of evicence of the KPI used in a construction project is not measurable. This is troublesome in the present development where KPI based management of construction projects are promoted, mainly due to the new opportunities given by digitalization [1,9].

One of the main characteristics of this EI is the measurement scale on which it measures the scientific evidence. Literature used six to eight-level differentiation between the evidence while the current EI is reduced to four level in order to facilitate a quicker appraisal of the LOE and in the same time better correspond to the 8-point scale of LOE. Furthermore, the four-point scale measurement technic is supporting the evaluator for learning the basic differences when an LOE is appraised. In terms of a design project aiming to deliver a public building, the four-point scale seems appropriate for grasping the array of choices. What might be debatable is that the first level of evidence includes opinions of recognized experts and the use of case studies. In a business where all the experts are proud of their years of experiences, it may generate tension between the stakeholders, depending on who is more trusted in the process. The development of both EI and LOE, described above, has its theoretical background in research theory in general 
and having the fact that research theory is internationally applicable indicates that the framework could also be internationally applicable. However, more research on different types of buildings and their contexts is needed to evaluate the general applicability of the proposed framework. Discussion of results from a case study exercise is somewhat a straightforward activity now. As any case study, results bear a low-quality level of evidence. In this investigation, it is also shown that the level of evidence cannot exceed fair. However, the experience for the single investigator had been meaningful, as going through a number of building criteria without finding appropriate scientific relevance triggered the curiosity for criteria that cannot be easily found. Regarding the generalizability of the given case study, the findings should be carefully examined. The case study outcome would suggest that a more comprehensive investigation should take place with different background of the investigators and preferably in a randomized manner. As for the PTS, the building criteria is a country-specific knowledge that requires a culturally appropriate building tradition. Employing the same PTS criteria outside of Sweden would not mean failure, but adaptations of the criteria must be considered. With regards to using the building criteria in another building typology, such as, a culture center [64] it can indicate that the builing critera are similar for other building types.

In the future research, an expert pool evaluation of the building criteria may shed light on the various best practice designated findings in the search for evidence. Furthermore, as a concern for the industry regarding cost efficiency, if fresh graduates on first- and second cycle could contribute to the evaluation of evidence, it would generate a more economically feasible way to extend the EI related research.

\section{Conclusions}

This study presents the first steps of an EI for a built environment. The study conceptualizes on the basis of the EBD stages a cognitive building solution that is capable of automatizing a series of repetitive and research related tasks regarding evidence appraisal and evaluation. The procedure to establish an EI for the built environment was tested through a case study, in which a novice research assistant approach to evidence appraisal was assessed. The 4-point rating scale, together with a diagram of which studies may fulfil the level of evidence requirements, was used to assess the building criteria. The concept of a cognitive building solution is preferable due to the strenuous job a person needs to perform when evaluating building criteria. The limitation of this study entailed a single evaluator for the transition process of the building criteria into LOE and later to EI. The EI is an initial step for establishing the cognitive building solution for EBD, in which the technological solution is rendered to serve a servitized construction product.

Author Contributions: Conceptualization, G.F. and P.J.; methodology, G.F.; formal analysis, G.F.; investigation, G.F.; resources, P.J.; data curation, G.F.; writing-original draft preparation, G.F.; writing-review and editing, G.F. and P.J.; visualization, G.F.; All authors have read and agreed to the published version of the manuscript.

Funding: This research received no external funding.

Institutional Review Board Statement: Not applicable.

Informed Consent Statement: Not applicable.

Data Availability Statement: Not applicable.

Acknowledgments: The authors would like to thank Kaj Granath for his insight and comments on this paper's first version. Furthermore, the authors are grateful for Regionfastigheter Jönköping for sharing their PTS documentation for research purpose.

Conflicts of Interest: The authors declare no conflict of interest. 


\section{References}

1. $\quad$ Fischer, M. Integrating Project Delivery; Wiley: Hoboken, NJ, USA, 2017.

2. Hafezparast Moadab, N.; Olsson, T.; Fischl, G.; Aries, M. Smart versus conventional lighting in apartments-Electric lighting energy consumption simulation for three different households. Energy Build. 2021, 244, 111009. [CrossRef]

3. Davoodi, A.; Johansson, P.; Henricson, M.; Aries, M. A conceptual framework for integration of evidence-based design with lighting simulation tools. Buildings 2017, 7, 82. [CrossRef]

4. Li, H.; Hong, T.; Lee, S.H.; Sofos, M. System-level key performance indicators for building performance evaluation. Energy Build. 2020, 209, 109703. [CrossRef]

5. Micolier, A.; Taillandier, F.; Taillandier, P.; Bos, F. Li-BIM, an agent-based approach to simulate occupant-building interaction from the Building-Information Modelling. Eng. Appl. Artif. Intell. 2019, 82, 44-59. [CrossRef]

6. Jang, H.; Kang, J. A stochastic model of integrating occupant behaviour into energy simulation with respect to actual energy consumption in high-rise apartment buildings. Energy Build. 2016, 121, 205-216. [CrossRef]

7. Johansson, P.; Fischl, G.; Granath, K. Towards Evidence-Based BIM. In The Advances in ICT in Design, Construction and Management in Architecture, Engineering, Construction and Operations (AECO): Proceedings of the 36th CIB W78 2019 Conference; University of Northumbria: Newcastle-upon-Tyne, UK, 2019.

8. Perjons, E.; Johannesson, P. A Value and Model Driven Method for Patient Oriented KPI Design in Health Care. In Biomedical Engineering Systems and Technologies; Springer: Berlin/Heidelberg, Germany, 2011; Volume 2011, pp. $123-137$.

9. Won, J.; Lee, G. How to tell if a BIM project is successful: A goal-driven approach. Autom. Constr. 2016, 69, 34-43. [CrossRef]

10. Arkitektur, C.F.V. Administrativa Arbetsplatser inom Vården och dess Förvaltningar. 2015. Available online: https://www. ptsforum.se/media/1082/2015-02-05-admarbplatser.pdf (accessed on 2 May 2021).

11. Baines, T.; Lightfoot, H.W. Servitization of the manufacturing firm. Int. J. Oper. Prod. Manag. 2014, 34, 2-35. [CrossRef]

12. Doni, F.; Corvino, A.; Bianchi Martini, S. Servitization and sustainability actions. Evidence from European manufacturing companies. J. Environ. Manag. 2019, 234, 367-378. [CrossRef] [PubMed]

13. Ulrich, R.; Zimring, C.; Zhu, X.; Dubose, J.; Seo, H.; Choi, Y.; Quan, X.; Joseph, A. A Review of the Research Literature on Evidence-Based Healthcare Design. HERD Health Environ. Res. Des. J. 2008, 1, 61-125. [CrossRef]

14. Hamilton, D.K.; Watkins, D.H. Evidence-Based Design for Multiple Building Types; John Wiley \& Sons: Hoboken, NJ, USA, 2009.

15. Levin, D.J. Defining Evidence-Based Design. Healthc. Des. Mag. 2008, 8, 8.

16. Preiser, W.F. Building performance assessment-from POE to BPE, a personal perspective. Archit. Sci. Rev. 2005, 48, 201-204. [CrossRef]

17. Preiser, W.; Vischer, J. Assessing Building Performance; Routledge: London, UK, 2006.

18. Davoodi, A.; Johansson, P.; Aries, M. The use of lighting simulation in the evidence-based design process: A case study approach using visual comfort analysis in offices. Build. Simul. 2020, 13, 141-153. [CrossRef]

19. Davoodi, A.; Johansson, P.; Aries, M. The Implementation of Visual Comfort Evaluation in the Evidence-Based Design Process Using Lighting Simulation. Appl. Sci. 2021, 11, 4982. [CrossRef]

20. Association, C.P. The Future for Construction Product Manufacturing, Digitalisation, Industry 4.0 and the Circular Economy; Construction Products Association: London, UK, 2016.

21. Li, P.; Froese, T.M.; Brager, G. Post-occupancy evaluation: State-of-the-art analysis and state-of-the-practice review. Build. Environ. 2018, 133, 187-202. [CrossRef]

22. Preiser, W.F.; White, E.; Rabinowitz, H. Post-Occupancy Evaluation (Routledge Revivals); Routledge: London, UK, 2015.

23. Malone, E.; Nanda, U.; Harmsen, C.; Reno, K.; Edelstein, E.; Hamilton, D.K.; Salvatore, A.; Mann-Dooks, J.R.; Oland, C. An Introduction to Evidence-Based Design: Exploring Healthcare and Design (EDAC Study Guides, Volume 1); The Center for Health Design: Concord, CA, USA, 2008.

24. Zimring, C.; Rosenheck, T. Post-Occupancy Evaluations and Organizational Learning1. In Learning from Our Buildings: A State-of-the-Practice Summary of Post-Occupancy Evaluation; National Academic Press: Washington, DC, USA, 2001 ; pp. 42-53.

25. Wickens, C.D.; Hollands, J.G.; Banbury, S.; Parasuraman, R. Engineering Psychology and Human Performance; Psychology Press: London, UK, 2015.

26. Ploennigs, J.; Ba, A.; Barry, M. Materializing the Promises of Cognitive IoT: How Cognitive Buildings Are Shaping the Way. IEEE Internet Things J. 2018, 5, 2367-2374. [CrossRef]

27. Peavey, E.; Vander Wyst, K.B. Evidence-Based Design and Research-Informed Design: What's the Difference? Conceptual Definitions and Comparative Analysis. Herd Health Environ. Res. Des. J. 2017, 10, 143-156. [CrossRef]

28. Cama, R. Evidence-Based Healthcare Design; John Wiley \& Sons: Hoboken, NJ, USA, 2009.

29. Pati, D. A Framework for Evaluating Evidence in Evidence-Based Design. Herd Health Environ. Res. Des. J. 2011, 4, 50-71. [CrossRef] [PubMed]

30. Stetler, C. Evidence-Based Practice and the Use of Research: A Synopsis of Basic Concepts $\mathcal{E}$ Strategies to Improve Care; NOVA Foundation: Washington, DC, USA, 2002.

31. Stichler, J.F. Research or evidence-based design: Which process should we be using? SAGE J. 2010, 4, 4. [CrossRef] [PubMed]

32. Stichler, J.F. Weighing the evidence. SAGE J. 2010, 3, 3. [CrossRef]

33. Marquardt, G.; Motzek, T. How to rate the quality of a research paper: Introducing a helpful algorithm for architects and designers. Herd Health Environ. Res. Des. J. 2013, 6, 119-127. [CrossRef] 
34. Evans, D. Hierarchy of evidence: A framework for ranking evidence evaluating healthcare interventions. J. Clin. Nurs. 2003, 12, 77-84. [CrossRef]

35. Chyung, S.Y.; Roberts, K.; Swanson, I.; Hankinson, A. Evidence-based survey design: The use of a midpoint on the Likert scale. Perform. Improv. 2017, 56, 15-23. [CrossRef]

36. Regionfastigheter, J.L. Program för Tekniskt Standard (Program for Technical Standard). Available online: https://www.ptsforum. se/ (accessed on 8 June 2021).

37. Athienitis, A.K.; Tzempelikos, A. A methodology for simulation of daylight room illuminance distribution and light dimming for a room with a controlled shading device. Sol. Energy 2002, 72, 271-281. [CrossRef]

38. Christoffersen, E.P.J.; Johnsen, K. An experimental evaluation of daylight systems and lighting control. Right Light. 1997, 15, 245-254.

39. Eleanor, S.L.; Glenn, D.H.; Robert, D.C.; Luis, L.F.; Sila, K.; Mary Ann, P.; Francis, M.R.; Stephen, E.S. Daylighting the New York Times Headquarters Building: Final Report: Commissioning Daylighting Systems and Estimation of Demand Response; Commissioning Daylighting Systems and Estimation of Demand Response: Berkeley, CA, USA, 2007.

40. Lighting, Z. The Lighting Handbook; Zumtobel Lighting: Dornbirn, Austria, 2013; p. A1-1.

41. Benya, J.R. Lighting for Schools; Educational Resources Information Center (ED): Washington, DC, USA, 2001.

42. Straker, L.; Abbott, R.A.; Heiden, M.; Mathiassen, S.E.; Toomingas, A. Sit-stand desks in call centres: Associations of use and ergonomics awareness with sedentary behavior. Appl. Ergon. 2013, 44, 517-522. [CrossRef] [PubMed]

43. Chandra, A.; Chandna, P.; Deswal, S.; Kumar, R. Ergonomics in the office environment: A review. In Proceedings of the International Conference on Energy and Environment, Chandigarh, Haryana, India, 23-24 March 2009.

44. Svensson, E. Bygg Ikapp Handikapp: Att Bygga för Ökad Tillgänglighet och Användbarhet för Personer med Funktionshinder: Kommentarer till Boverkets Byggregler, BBR; Svensk Byggtjänst: Eskilstuna, Sweden, 2006.

45. Karjalainen, S. Thermal comfort and use of thermostats in Finnish homes and offices. Build. Environ. 2009, 44, 1237-1245. [CrossRef]

46. Karjalainen, S. Usability guidelines for room temperature controls. Intell. Build. Int. 2010, 2, 85-97. [CrossRef]

47. Jaakkola, J.J.; Reinikainen, L.M.; Heinonen, O.P.; Majanen, A.; Seppänen, O. Indoor air quality requirements for healthy office buildings: Recommendations based on an epidemiologic study. Environ. Int. 1991, 17, 371-378. [CrossRef]

48. Hyttinen, M.; Pasanen, P.; Salo, J.; Björkroth, M.; Vartiainen, M.; Kalliokoski, P. Reactions of Ozone on Ventilation Filters. Indoor Built Environ. 2003, 12, 151-158. [CrossRef]

49. Ohno, Y. CIE fundamentals for color measurements. In Proceedings of the NIP \& Digital Fabrication Conference; Society for Imaging ScienceTechnology: Springfieldu, VA, USA, 2000; pp. 540-545.

50. Figueiro, M.; Nagare, R.; Price, L. Non-visual effects of light: How to use light to promote circadian entrainment and elicit alertness. Light. Res. Technol. 2018, 50, 38-62. [CrossRef] [PubMed]

51. Morrow, B.; Kanakri, S. The Effect of LED and Fluorescent Lighting on Children in the Classroom; EDRA: Oklahoma City, OK, USA, 2018.

52. Wang, M.L.; Luo, M.R. Effects of LED lighting on office work performance. In Proceedings of the 201613 th China International Forum on Solid State Lighting (SSLChina), Beijing, China, 15-17 November 2016; pp. 119-122.

53. Borisuit, A.; Linhart, F.; Scartezzini, J.-L.; Münch, M. Effects of realistic office daylighting and electric lighting conditions on visual comfort, alertness and mood. Light. Res. Technol. 2015, 47, 192-209. [CrossRef]

54. Svensk Standard, S. 25268: 2007. Byggakustik-Ljud. Av Utrymmen I Byggn. -VårdlokalerUndervis. Dag-Och FritidshemKontor Och Hotel; Swedish Institute for Standards: Stockholm, Sweden, 2007.

55. Boyce, P.; Hunter, C.; Howlett, O. The Benefits of Daylight through Windows; Rensselaer Polytechnic Institute: Troy, NY, USA, 2003.

56. Löfberg, H.A.; Bäck, B.; Glaas, F. Räkna Med Dagsljus; Statens Institut för Byggnadsforskning: Gävle, Sweden, 1987.

57. Elstandard, S.S. Elinstallationsreglerna SS 43640 00, utgåva 3, med kommentarer; SEK Svensk Elstandard: Stockholm, Sweden, 2017.

58. Tyrväinen, L.; Ojala, A.; Korpela, K.; Lanki, T.; Tsunetsugu, Y.; Kagawa, T. The influence of urban green environments on stress relief measures: A field experiment. J. Environ. Psychol. 2014, 38, 1-9. [CrossRef]

59. Farley, K.M.; Veitch, J.A. A Room with a View: A Review of the Effects of Windows on Work and Well-Being; Citeseer: Princeton, NJ, USA, 2001.

60. Li, H.; Chau, C.K.; Tang, S.K. Can surrounding greenery reduce noise annoyance at home? Sci. Total Environ. 2010, 408, 4376-4384. [CrossRef]

61. för Vårdhygien, S.F. Byggenskap och vårdhygien. In Vårdhygieniska Aspekter vid ny-och Ombyggnation samt Renovering av vårdlokaler; Arbetsgruppen BOV (Byggenskap och Vårdhygien): Stockholm, Sweden, 2003.

62. Gedda, M. Evidence-based medicine, evidence-based practice and evidence index 1.0 (EVID-i). Kinésithér. Rev. 2017. [CrossRef]

63. Polit, D.F.; Beck, C.T. Nursing Research: Generating and Assessing Evidence for Nursing Practice; Lippincott Williams \& Wilkins: Philadelphia, PA, USA, 2008.

64. Huovila, P.; Hyvärinen, J.; Granath, K.; Johansson, P.; Bruun, C.; Annerstedt, J. Value Driven Procurement in Building and Real Estate-Final Report; VTT Technical Research Centre of Finland: Espoo, Finland, 2012. 